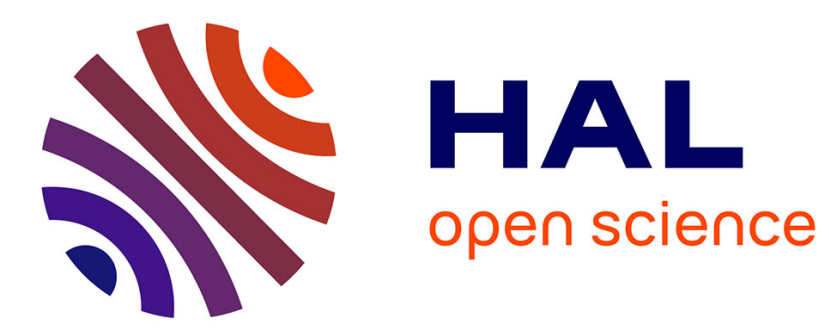

\title{
Impact of maintenance operations on the seasonal evolution of ditch properties and functions
}

Jeanne Dollinger, Fabrice Vinatier, Marc Voltz, Cécile Dagès, Jean-Stéphane Bailly

\section{- To cite this version:}

Jeanne Dollinger, Fabrice Vinatier, Marc Voltz, Cécile Dagès, Jean-Stéphane Bailly. Impact of maintenance operations on the seasonal evolution of ditch properties and functions. Agricultural Water Management, 2017, 193, pp.191-204. 10.1016/j.agwat.2017.08.013 . hal-01591538

\section{HAL Id: hal-01591538 \\ https://hal.science/hal-01591538}

Submitted on 21 Sep 2017

HAL is a multi-disciplinary open access archive for the deposit and dissemination of scientific research documents, whether they are published or not. The documents may come from teaching and research institutions in France or abroad, or from public or private research centers.
L'archive ouverte pluridisciplinaire HAL, est destinée au dépôt et à la diffusion de documents scientifiques de niveau recherche, publiés ou non, émanant des établissements d'enseignement et de recherche français ou étrangers, des laboratoires publics ou privés. 
Impact of maintenance operations on the seasonal evolution of ditch properties and functions

Jeanne Dollinger*1, Fabrice Vinatier ${ }^{1}$, Marc Voltz ${ }^{1}$, Cécile Dagès ${ }^{1}$, Jean-Stéphane Bailly ${ }^{2}$

${ }^{1}$ INRA, UMR LISAH, 2 place Pierre Viala, 34060 Montpellier Cedex 1, France

${ }^{2}$ AgroParisTech, UMR LISAH, 2 place Pierre Viala, 34060 Montpellier Cedex 1, France

DOI: http://dx.doi.org/10.1016/j.agwat.2017.08.013

Abstract: Ditch networks were traditionally designed to protect fields from soil erosion or control waterlogging. They are still frequently managed by either mowing, chemical weeding, dredging or burning to ensure their optimal hydraulic capacity. Ditches were recently reported also to improve water quality and sustain biodiversity. These ditch functions are related to specific ditch properties. By contrastingly modifying ditch properties, maintenance operations were supposed to regulate these functions. There is, therefore, a need to re-examine the design and maintenance strategies of ditches to optimize the whole range of ecosystem services that they provide. In this study, we address the innovator question of how maintenance operations affect the yearly evolution of ditch properties, and in turn, the panel of functions that ditches support. During one year, we monitored the vegetation, litter, soil properties, and ash cover of five ditches that were being unmanaged, dredged, mowed, burned, and chemically weeded, respectively, with timing and frequency as generally operated by farmers in the study area. We then used indicators to evaluate the effect that the evolution of these properties has on the ditch water conveyance, herbicide retention and biodiversity conservation functions. We found that the evolution of these properties significantly contrasted among the 5 maintenance strategies. All the maintenance operations cleared the vegetation, which improves the hydraulic capacity by up to 3 times. The optimal hydraulic capacity is maintained longer after chemical weeding and dredging, but these operations have negative impacts on the herbicide retention and biodiversity conservation functions. The litter and ash layers generated by mowing and burning, 
be an efficient tool for optimizing ditch functions. The choice of maintenance operation and timing are key to successfully optimizing most of the functions that ditches can support.

Keywords: Maintenance operations; intermittently flooded ditch; ecosystem services; herbicides retention; water conveyance; biodiversity conservation

\section{Highlights:}

- We used indicators to evaluate the evolution of ditch functions after maintenance.

- Maintenance is an efficient and operational tool for optimizing ditch functions.

- The choice of maintenance operation and timing are key to optimize multiple functions.

- The primary 4 maintenance operations generate contrasted ditch properties evolution.

- Burning and mowing improved the best water quality and biodiversity functions.

\section{Introduction}

Farm ditches are infrastructures that have been used for centuries by farmers to regulate excess water fluxes in cropped areas, which, depending on the pedoclimatic context, were used either to protect crop fields from soil erosion or to control waterlogging (Dollinger et al., 2015; Levavasseur, 2012; Levavasseur et al., 2014). The design of these human-made channels, which are arranged as networks in cropped catchments, was optimized over time to efficiently collect runoff and drainage fluxes and rapidly evacuate them towards receiving water bodies (Levavasseur et al., 2014, 2016). Additionally, these infrastructures have also recently been reported to sustain biodiversity, buffer agricultural nonpoint source pollutions or participate in groundwater recharge and flood regulation, depending on their properties (e.g., Dollinger et al., 2015; Herzon and Helenius, 2008; Needelman et al., 2007).

As part of a more global strategy that aims to limit the adverse effects of intensive agriculture on the environment, the interest in promoting those ditch functions that are not directly involved in protecting crops from waterlogging and soil losses is growing (Dollinger et al., 2015; Herzon and Helenius, 2008; Needelman et al., 2007). This interest is particularly the case for non-point source pollution buffering and biodiversity conservation ditch functions. For instance, pesticides sprayed in intensive crop systems to protect crops from pests and weeds may be partly dissolved by runoff and drainage fluxes and then transferred towards surface water bodies or groundwater via ditch networks (Louchart et al., 2001; Tang et al., 2012). This non-point source pollution threatens the quality and 
ecological health of these water bodies, thereby restricting specific usages, such as drinking water supply, and engendering significant depollution costs around the world (Reichenberger et al., 2007; Schultz et al., 1995). Therefore, there is a need to re-examine the design and maintenance strategies of ditches to optimize the whole range of ecosystem services that they provide. In this paper, we address the specific issue of the impact of maintenance practices on the ditch functions. Ditches are distinguished here from irrigation channels, as, even though they might share design and maintenance similarities, their flooding regime is greatly contrasted.

Ditch maintenance strategies originally aimed to preserve an optimal hydraulic capacity thanks to frequent vegetation clearance (Dollinger et al., 2015; Levavasseur et al., 2014, 2016). Ditch maintenance primarily consists of the succession in time and location of some of the 4 basic operations, which are ditch mowing, dredging, chemical weeding and burning (Dollinger et al., 2015; Levavasseur, 2012). The frequency and timing of these maintenance operations differ. Ditch dredging is usually performed once every 5 to 10 years but can be more frequent in the case of small in-field ditches that are designed to protect sloping croplands from erosion (Bailly et al., 2015a; Levavasseur, 2012; Smith and Pappas, 2007). Mowing, chemical weeding and burning are usually performed at least once a year (Bailly et al., 2015a; Levavasseur, 2012; Levavasseur et al., 2014; Smith and Pappas, 2007). Moreover, a given ditch is very likely to undergo a combination of maintenance operations every year. While chemical weeding, mowing and dredging are usually performed from spring to late summer, burning is performed in winter when the vegetation dries out. This operation is thereby restricted to the highland or semi-arid areas where there is no base-flow in the ditches during winter (e.g., Bailly et al., 2015a).

The maintenance of ditches, by modifying their properties, also modulates the occurrence and intensity of the biogeochemical processes involved in the multiple functions supported by ditches (Dollinger et al., 2015). The change in ditch properties after maintenance may favour certain functions over others as an intensity shift of a given biogeochemical process may favour a function or a group of functions and be disadvantageous to others (Dollinger et al., 2015). Designing ditch maintenance strategies for sustaining a panel of functions, including those for which the ditches were created, requires a good knowledge of how each maintenance operation modifies the ditch properties, not only immediately but also after their mid-term evolution. Few studies have attempted to describe the spatial and temporal variability of ditch properties along networks and link them to maintenance strategies (Bailly et al., 2015a; Lecce et al., 2006; Levavasseur et al., 2014). However, to our knowledge, the effect of the maintenance operations on the mid- evolution of ditch properties and how this evolution affects a panel of functions has never been described in the literature. 
In accordance with these gaps of knowledge, the objectives of this study are to i) experimentally assess the mid-term evolution of ditch properties after each maintenance operation, ii) evaluate with semiquantitative indicators the influence of these ditch property evolutions on the hydraulic capacity, herbicide retention and biodiversity of the ditches, and iii) try to identify maintenance operations or strategies that could jointly sustain a panel of functions. The study was conducted during one year in South of France in a vineyard area that is subjected to rare but highly intensive rainfall events and where ditch networks were originally designed to prevent soil erosion.

\section{Materials and methods}

\subsection{Experimental design}

\subsubsection{Study site}

The study site is located in the downstream part of the Bourdic catchment in South of France $\left(43^{\circ} 5^{\prime}\right.$ Nord, $3^{\circ} 3^{\prime}$ East). This $6.4 \mathrm{~km}^{2}$ catchment, primarily covered by vineyards, is subject to a Mediterranean climate, which is characterized by rare but high-intensity rainfall events that occur mostly in spring and fall (Levavasseur et al., 2012). The dense ditch network is managed in the catchment with the principal aim of preventing soil loss by erosion (Levavasseur et al., 2016).

The study site is a ditch receiving both drainage (groundwater exfiltration flux) and runoff (overland flow) water from the surrounding vineyards. The ditch length is approximately $120 \mathrm{~m}$, its bottom width $64 \mathrm{~cm}$, its top width $160 \mathrm{~cm}$, its depth $54 \mathrm{~cm}$ and its slope $0.33 \%$. As described in Fig. 1, for the experiments, the ditch was divided into 4 sections or "patterns", each sub-divided into 5 quadrats being $4 \mathrm{~m}$ long each. The first quadrat of each pattern is an un-managed control. Then, proceeding from the upstream to downstream direction, the quadrats are dredged, mowed, burned and chemically weeded, respectively. Moreover, the quadrats are separated from each other by 2-m long unmanaged buffer sections.

The ditch was equipped, in the middle unmanaged area, with a capacity sensor (Crabit et al., 2011a; Crabit et al., 2011b), which monitored the water level fluctuations with a 60-min frequency. Two water wells, one located upstream and the second $100 \mathrm{~m}$ downstream from the ditch outlet, allowed the manual monitoring of the groundwater level. Rainfall data were obtained from the Roujan catchment meteorological station located only $1.5 \mathrm{~km}$ from the study site. 
The monthly cumulated rainfall amounts during the experiment period were compared to the rainfall distributions observed at the same meteorological station from 1992 to 2016 (Fig. S1). This comparison shows that fall 2015 was dryer than usual. Indeed, the cumulated rainfall amounts for September, October and November were in the very bottom range of the rainfall distributions for these months. Moreover, spring 2015 was slightly dryer than usual, particularly in May, but spring 2016 was slightly wetter.

\subsubsection{Maintenance design}

The maintenance strategy was designed to mimic the frequencies and timings typically used by farmers in the study area (Levavasseur et al., 2014). The first maintenance campaign was initiated on April $7^{\text {th }}$, 2015 with burning and chemical weeding. The dredging operations were spread between April $23^{\text {rd }}$ and May $5^{\text {th }}, 2015$ because of the greatly differing soil humidity conditions among the patterns. Mowing was performed on June $4^{\text {th }}$ and then again on September $7^{\text {th }}, 2015$. The second campaign started on February $17^{\text {th }}, 2016$ with burning, then chemical weeding on April $13^{\text {th }}, 2016$. A given quadrat was submitted only to one maintenance operation type throughout the experiment. Figure 2 depicts how each management operation was performed for this study.

\subsubsection{Monitoring of ditch properties}

The ditch properties were surveyed on each quadrat using a semi-quantitative method (Bailly et al., 2015a; Dollinger et al., 2016; Levavasseur et al., 2014). This method consists of first, precisely measuring the morphological properties of the ditch in each pattern. The cross-section profile (upper width, lower width and depths) was measured manually, whereas the length and slope were measured with a theodolite and a differential GPS. Second, in each quadrat, the proportion of the ditch bottom and walls covered by vegetation, litter and ash (in \%) and the depths of these respective layers (in $\mathrm{cm}$ ) were visually estimated. The visual estimations were initially performed by 2 independent observers and then calibrated against each other. The precision of the estimates was approximately 10 to $15 \%$ for the covering area and $1 \mathrm{~cm}$ for the material layer depth. Last, the litter was classified into 3 different types (dead leaves, hay, and decayed plant residues) and the vegetation into either an herbaceous or ligneous type. During the surveys, the vegetation height was classified as $<15 \mathrm{~cm},>15 \mathrm{~cm}$ or mixed (several vegetation heights all between 0 and $15 \mathrm{~cm}$ ) and then, converted to $10 \mathrm{~cm}$ (maximal vegetation height in this class), $54 \mathrm{~cm}$ and $15 \mathrm{~cm}$ (maximal vegetation height in this class) height for each class, respectively. The vegetation classified as $>15$ is, most of the time, as high or even higher than the ditch depth $(54 \mathrm{~cm})$ which was thereby taken as default value for this class as it's the maximum 
vegetation height that can influence the various ditch functions. The presence or absence of flowers was also monitored.

The surveys were conducted every 15 days between April and July and then every month the remainder of the year. In total, 19 ditch property monitoring surveys were conducted between April 2015 and May 2016.

Soil samples were collected in the upper horizon $(0-2 \mathrm{~cm})$ of the 4 control quadrats during July 2015 for physicochemical properties measurements. The particle size distributions, $\mathrm{pH}$ values, cation exchange capacities (CEC) and organic carbon content of the soil samples were measured at the INRA Soil Analysis Laboratory in Arras (France) using normalized methods. Particle size distribution was measured with the standardized method NF X 31-107, $\mathrm{pH}_{\mathrm{H} 2 \mathrm{O}}$ with the method NF ISO 10390, CEC Metson with the method NF X 31-130 and OC content with the method NF ISO 10694. To detect any change in soil properties according to the maintenance operations, these properties were again measured on the soil samples collected from the upper $2 \mathrm{~cm}$ layer on all quadrats during April 2016, i.e., after approximately 9 months of the distinct maintenance strategies.

The soil bulk densities were estimated by sampling a known volume of soil and measuring the dry weight after oven drying for $24 \mathrm{~h}$ at $105^{\circ} \mathrm{C}$. Six replicates were performed for each quadrat during April 2016.

\subsection{Calculation of the pesticide retention indicator}

For a given pesticide, the retention capacity of a ditch depends on its properties and more specifically, on the abundance and characteristics of the ditch materials in contact with the water column (Dollinger et al., 2016). Dollinger et al. (2016) proposed the sorption-induced pesticide retention indicator (SPRI), which is based on a pesticide mass balance equation and integrates the influence of several factors to evaluate the proportion of pesticides that is potentially retained by sorption processes as it passes through a ditch during a flood event. The factors integrated into the calculation of the SPRI indicator are i) the amount and properties of ditch materials in contact with the water column, ii) the pesticide sorption properties and iii) the flood characteristics (volume, water level). For the purpose of this study, this indicator was used as a means to compare how the different implemented maintenance designs affect the herbicide retention functions of the ditches.

$\operatorname{SPRI}(\%)=\frac{\sum_{i=1}^{n} M_{i} K d_{i}}{\sum_{i=1}^{n} M_{i} K d_{i}+V} 100$ 
where $M_{i}$ is the mass of material $i$ and $i$ is one of the ditch materials [soil (s), decaying (DV) and living vegetation (veg) (g)]; $K \mathrm{~d}_{i}$ is the sorption coefficient of material $i$ and $V$ is the volume of water flowing through the ditch during a flood event $\left(\mathrm{cm}^{3}\right)$.

The theory and hypotheses underlying the estimation of pesticide retention in ditches during a flood event with SPRI are detailed in Dollinger et al. (2016). The SPRI indicator was calculated for 2 herbicides, glyphosate (N-(Phosphonomethyl)glycine) and diuron (3-(3,4-dichlorophenyl)-1,1dimethyl-urea), which are frequently detected in the water columns of ditches in the study area at concentrations reaching up 1,000 $\mathrm{g} \mathrm{I}^{-1}$ (Dages et al., 2015; Louchart et al., 2001). The SPRI values were calculated for both herbicides on the 19 dates during the year when the ditches were surveyed and for all 20 quadrats. The sorption coefficients of diuron used for the SPRI calculation were $8.61 \mathrm{~kg}^{-1}$ for soil, $3.2 \mathrm{I} \mathrm{kg}^{-1}$ for plants, $46.5 \mathrm{I} \mathrm{kg}^{-1}$ for dead leaves, $28.6 \mathrm{I} \mathrm{kg}^{-1}$ for mowing residues and $1,009.1 \mathrm{I} \mathrm{kg}^{-1}$ for ash; those of glyphosate were $26.2 \mathrm{I} \mathrm{kg}^{-1}$ for soil, $2.01 \mathrm{~kg}^{-1}$ for plants, $4.4 \mathrm{I} \mathrm{kg}^{-1}$ for dead leaves, $0.8 \mathrm{I} \mathrm{kg}^{-1}$ for mowing residues and $23.6 \mathrm{I} \mathrm{kg}^{-1}$ for ash (Dollinger et al., 2016).

The masses of the soil, vegetation, litter and ash materials were calculated as described in Dollinger et al. (2016) from the ditch properties estimated during the surveys, namely, the percentages of the ditch bottom coverage, depths, porosities and bulk densities of all material layers. The values of porosity factors used were those described in Dollinger et al. (2016) for each type of material. The volume of flowing water was set to $122 \mathrm{~m}^{3}$, which corresponds to a typical flood event in the study area generated by a one-month return period rainfall event (Bailly et al., 2015a). The flood usually generated by this type of event lasts approximately $12 \mathrm{~h}$ and $20 \mathrm{~min}$, and its flow rate is approximately $2.7510^{-3} \mathrm{~m}^{3} \mathrm{~s}^{-1}$.

\subsection{Calculation of the hydraulic capacity}

The waterlogging control and soil erosion prevention functions, for which ditches were created and managed, both rely on an efficient water conveyance capacity of the ditches (Dollinger et al., 2015). The water conveyance capacity of ditches is related to their shape and roughness (Boutron et al., 2011; Crabit et al., 2011b). The maximal flow rate $\left(Q_{\max }\right)$, which is reached when the water level equals the ditch depth, is also called the hydraulic capacity or water conveyance capacity. This value was calculated using the Manning-Strickler equation (Strickler, 1923) and assuming flow uniformity (Eq. 2)

$Q_{\max }=K S R h^{2 / 3} i^{1 / 2}$

(Equation 2) 
where $Q_{\max }$ is the water conveyance capacity $\left(\mathrm{m}^{3} \mathrm{~s}^{-1}\right), K$ is the Strickler coefficient $\left(\mathrm{s}^{-1}\right), i$ is the slope(m $\left.\mathrm{m}^{-1}\right), S$ is the ditch wet cross-section area $\left(\mathrm{m}^{2}\right), R h$ is the hydraulic radius $(\mathrm{m})$ or the $S / P$ ratio, and $P$ is the wetted perimeter $(\mathrm{m})$.

The primary source of roughness in the ditches is the vegetation (e.g., Jarvela, 2002; Wu et al., 1999). The roughness coefficients (Strickler coefficients, $K$ ) were estimated from the vegetation cover data using the empirical Strickler database developed by Bailly et al., (2015b) from measurements in an hydraulically equipped ditch with variable vegetation patches (Vinatier et al., In Press).

The ditch cross-section was considered trapezoidal and is characterized by the ditch bottom and top widths and by the ditch depth. The wet cross-section area (S) is equivalent to the ditch cross-section surface area as the water level equals the ditch depth in the calculation of the hydraulic capacity. The wetted perimeter $(\mathrm{P})$ is the sum of the ditch bottom and sidewalls length and the hydraulic radius $(\mathrm{Rh})$ is the ratio between $S$ and $P(S / P)$.

The water conveyance capacity of the 20 quadrats was calculated for the 19 dates during the year when ditches were surveyed.

\subsection{Establishment and calculation of the ecological indicators}

The ditches sustain biodiversity in croplands by providing shelter, food and protected pathways for connecting different populations of auxiliary insects, mammals, frogs or birds (Herzon and Helenius, 2008; Marja and Herzon, 2012). The link between the ditch properties and the abundance of certain categories of insects or macrofauna has never been empirically quantified but can be approached thanks to the work conducted on riverine landscapes (Ward, 1992), dry riverbeds (Steward et al., 2012; Wishart, 2000), non-perennial streams (Chester and Robson, 2011) and riparian vegetation (Stella et al., 2013). We assumed that the relations between systems characteristics and the biodiversity described in those studies could be extended to Mediterranean ditches. The works of Dangles et al. (2004), Johnson et al. (2003) and Murphy et al. (2012) show that detritivore insects are the primary consumers of litter in several types of ecosystems. This category of insects relies on a sufficient litter cover as their food sources. We thereby assumed that the litter layer in ditches favours these insects. Second, the linear vegetated elements of landscapes improve the survival and development of insects (Meier et al., 2005) and macrofauna (Andreassen et al., 1996) populations by providing sheltered corridors. However, the surface of the ditch covered by vegetation and the vegetation height modulate the shelter effect of a given ditch. Last, the blooming vegetation provides sources of nectar for auxiliary insects (Nicholls et al., 2001; Sarthou et al., 2005). 
To evaluate the influence of the ditch properties evolution on their ecological functions, we derived qualitative indicators from these general ecological principles. These indicators are not designed to quantify or qualify the progression of the biodiversity based on the progression of the ditch properties, which would require more empirical work. The indicators only intend to describe the progression of the conditions sustaining or disadvantaging the biodiversity as a function of the ditch properties. Based on the ecological principles, we divided the ditch into 3 layers, the litter, vegetative and canopy layers and computed an ecological indicator for each. The three indicators were calculated for each quadrat as binary functions with thresholds for the respective layers based on i) the litter and surface covering, ii) the vegetation height and surface covering, and iii) the presence of flowers. Considering the absence of experimental data on these ecological functions in the ditches, we arbitrarily chose the thresholds in accordance with the works on closed ecosystems (Andreassen et al., 1996; Chester and Robson, 2011) and to emphasize the difference between the maintenance treatments. The thresholds for the litter layer were defined as $5 \mathrm{~cm}$ and $50 \%$ for height and cover, respectively. The thresholds for the vegetation layer were defined as $20 \mathrm{~cm}$ and $50 \%$ for height and cover, respectively. Finally, the threshold for the canopy layer was defined as the presence of at least 1 flower in the quadrat. For a given quadrat, the value of every indicator is either 0 or 1 . The value 1 represents a situation favouring the biodiversity. For a given treatment, the value of every indicator is the average of the 4 replicates and can, therefore, take the values $0,0.25,0.5$ and 1 .

\section{Results}

\subsection{Influence of the maintenance operations on the mid-term evolution of ditch properties}

Figure 3 describes the evolution of the living vegetation layer in all the treatments throughout the year. It must be noted that the high variability of the vegetation height that can be observed among the 4 replicates of a given treatment is partly due to the conversion of vegetation height classes into vegetation height. Figure 4 describes the contrasted evolution of the litter layers and Figure 5 the difference in soil physicochemical properties among the treatments.

At the beginning of the experiments in April 2015, vegetation covered only approximately $30 \%$ of the ditch bottom surface area and was short and scattered. At that time, the vegetation cover was homogeneous all along the ditch. No litter or ash covering could be observed on any of the 20 quadrats and the soil physicochemical properties were relatively homogeneous among the 4 control quadrats. 
The evolution of the ditch properties for the 5 treatments, namely, no management, dredging, mowing, burning and chemical weeding between April 2015 and May 2016 are described hereafter.

For the control treatment, the bottom surface areas of the quadrats were progressively colonized by vegetation during the spring and summer (Fig. S2). The total vegetation covering was reached by about September for all the control quadrats and persisted throughout the fall. Then, the vegetation cover progressively decreased from December 2015 to April 2016. It must be noted that the vegetation covering and density was higher in April 2016 than at the beginning of the experiments in April 2015. This difference is probably due to the contrasting maintenance history in the previous year. Indeed, before April 2015, the ditch was intensively managed, whereas between April 2015 and 2016, it was left unmanaged. The evolution of the relative surface area covered by vegetation was progressive throughout the year, but the vegetation growth and densification was very quick for this treatment. Moreover, the litter layers on the control quadrats were scattered and thin until December, when the progressive vegetation senescence generated a few litter inputs. The major litter inputs were due to the collection of dead leaves from the surrounding vineyards during January 2016. The amount of dead leaves collected considerably varied among the patterns because of their different orientation regarding the dominant wind direction and vine rows. The control quadrats from patterns 2 to 4 collected most of this litter, whereas the control quadrat of the first pattern, which was not perpendicular to the wind direction, collected almost nothing. The decrease of the litter layer depth with time can be attributed to a progressive biotransformation and the settling generated by the successive floods. Furthermore, the topsoil physicochemical properties only slightly evolved between July 2015 and April 2016 on the control quadrats. A slight decrease in the clay fraction in favour of the silt fraction can be reported as well as a slight $\mathrm{pH}$ rise. The organic carbon content and CEC did not significantly change.

After the dredging treatment operation in April 2015, the vegetation recolonized the bottom surface area of the quadrats very progressively throughout the year and stayed relatively short and scattered (Fig. S3). The vegetation senescence during winter was weak and generated only very few litter inputs. Similar to the control treatments, the primary litter provision was ensured by the collection of dead leaves from the surrounding vineyards. These litter inputs were also heterogeneous among the patterns, and an identical decrease in the litter layer depth was observed for both the control and dredged quadrats. The particle size distribution of the topsoil on the dredged quadrats was very similar to that of the controls on the same date and so were the $\mathrm{pH}$ values. However, the bulk density, CEC and organic carbon content were slightly lower. During the dredging, a layer of $15 \mathrm{~cm}$ of soil was excavated, which corresponded to the first horizon enriched in organic matter compared to the deeper 
layers. Accordingly, the values of CEC and organic carbon content were similar for the dredged top soil and the second horizon in 2015 (data not shown).

For the mowing treatment, the vegetation recolonization and growth after each maintenance operation were very quick, particularly after the second operation in September due to more favourable hydric conditions (Fig. S4, Fig. 6). Both of the mowing operations generated consequent litter layers that were supplemented during winter by the collection of dead leaves. These mowed quadrats were partly or even completely covered by more or less deep litter layers throughout the year. The physicochemical properties of the topsoil of these quadrats were very similar to that of the control.

For the burning treatment, the vegetation recolonization in the months following the two burnings was very progressive, but the vegetation growth and densification were very quick (Fig. S5). For this treatment, the litter layer in the quadrats was quasi-inexistent until the dead leaves collection during January 2016. This litter was then rapidly eliminated in February 2016 during the second burning operation. The burning residues or ashes covered the ditch surface until July and then progressively dissipated until the end of August when the ash residues could no longer be observed at the ditch surface. The majority of these ashes were not washed out by the big floods during August (Fig. 6) but were found by visual inspection to be infiltrated and bound to soil down to 2 to $5 \mathrm{~cm}$ depth. The ashes seem to have undergone a similar fate after the burning operations that occurred before the experiments, as several soil-bound ash layers were observed at different depths in the soil profile. The physicochemical properties of the topsoil of these quadrats were very similar to those of the control except the $\mathrm{pH}$ values, which were higher. The higher $\mathrm{pH}$ is consistent with the alkaline properties of ashes (Dollinger et al., 2016).

Finally, for the chemical weeding treatment, vegetation senescence was observed during the 2 months following each maintenance operation, and then, the vegetation started to recolonize the ditch surface. The dynamic of the vegetation recolonization was relatively rapid afterwards, but the plants stayed rather short and scattered (Fig. S6). The vegetation decay after the chemical weeding generated a wide but thin litter layer. For the other treatments, the litter layer increased during January on the chemically weeded quadrats due to the dead leaves collected from neighbouring fields. The physicochemical properties of the topsoil of these quadrats were very similar to that of the control. 
The estimated hydraulic capacity or maximal flow rate that a ditch can carry without overflowing $\left(Q_{\max }\right)$ varied only slightly, i.e., from 7.6 to $14 \mathrm{I} \mathrm{s}^{-1}$, on average, for the control quadrats (Fig. 7). Indeed, these quadrats contained a dense vegetation cover from April 2015 to May 2016 (Fig. 3). The dense vegetation fills the ditches and thereby limits the water volume that they can carry and induces flow resistance (e.g., Crabit et al., 2011b; Jarvela, 2002). By clearing the vegetation cover, all the maintenance operations rapidly improved the hydraulic capacity of the ditches (Fig. 7). However, the different dynamics of the ditch recolonization by vegetation after the four maintenance strategies generated diverse evolutions of the hydraulic capacity as described in Fig. 6 . These contrasting changes are not only due to the type of maintenance operation but also to the maintenance calendar.

The effect of dredging, mowing and burning on the hydraulic capacity immediately resulted in an increased $Q_{\max }$ i.e., by 4 times compared to the control treatment. In contrast, after the chemical weeding operations, a vegetation clearing took longer than for the other maintenance operations and the optimal hydraulic capacity was reached only approximately a month after each operation. The hydraulic capacity dropped (Fig. 7) as the vegetation recolonized the ditches (Fig. 3). Generally, the $\mathrm{Q}_{\max }$ decreased to the level of the control quadrat within 1 to 3 months, depending both on the maintenance operations performed and on the calendar. As an example, when the mowing was performed during June, i.e., during the dry season, this operation helped maintain an optimal $Q_{\max }$ during the following 2 months, whereas the $Q_{\max }$ dropped to the control treatment level within a month when performed during September.

Dredging was performed in spring, and therefore, the hydraulic capacity of these quadrats was optimal during spring and early summer. This maintenance design optimizes the ditch hydraulic capacity for the storms that generate massive runoff amounts and have a high occurrence frequency during spring in the study area (Fig. S1) (Levavasseur et al., 2014; Moussa et al., 2002). On the other hand, the hydraulic capacity is minimal under this maintenance design during late summer and fall when the highest intensity rainfall events generally occur in the study area (Fig. S1) (Moussa et al., 2002). Mowing was performed in June and September, and $Q_{\max }$ was optimal from June to the beginning of August and from September to October. The occurrence probability of high-intensity rainfall events in June and July is very low. However, this maintenance design optimizes the ditch hydraulic performance for the big storms that usually occur between late summer and fall. The optimal hydraulic capacity was maintained longer under the chemical weeding design than under the others. However, the chemical weeding was performed once a year during April, and thus the hydraulic capacity of the ditches was at 
was performed during April 2015 and then again during February 2016, which generated an optimal hydraulic capacity for the floods occurring in spring but not for those in fall.

\subsubsection{Herbicide retention}

At the scale of a flood event, sorption was reported to be the primary pesticide retention mechanisms in ditches (Dollinger et al., 2015; Stehle et al., 2011). The SPRI indicator provides estimations of the herbicide fractions potentially retained by sorption on the ditch bottom during a flood event (Dollinger et al., 2016). Figure 8 shows the evolution of the SPRI values for the 2 herbicides, diuron and glyphosate, on the control quadrats and the difference, which is either positive or negative, that the changes in the ditch properties due to the different maintenance strategies imply regarding herbicide retention.

For the control quadrats, the glyphosate SPRI values did not evolve between April 2015 and May 2016. This outcome is consistent with the relative affinity and masses of the different ditch materials (Dollinger et al., 2016). Indeed, glyphosate has a very high sorption affinity for soils and a reduced sorption affinity for litters and living vegetation. Moreover, the mass of living vegetation and litters is slight compared to the mass of soil in contact with the ditch water column. The glyphosate sorption capacity of ditches is thereby mostly driven by the properties of their soils. Soil properties did not significantly change during the study period. The average glyphosate SPRI value for the control treatments was $29 \%$. The SPRI values of diuron for the control treatment did not evolve until January 2016 but then increased by approximately 3\%. The sorption affinity of diuron for the different ditchbed materials is different than that of glyphosate, i.e., low for living vegetation, moderate for soil, high for litters and very high for ash. The soil properties did not evolve, and the litter layer was very scarce until January 2016, when the ditch collected dead leaves from the surrounding vineyards, which improved the diuron retention capacity.

Chemical weeding and mowing had no effect on the glyphosate retention capacity of the ditches estimated with SPRI. On the other hand, the dredging slightly decreased the glyphosate retention capacities while burning increased the retention by approximately $3 \%$ during the periods when ashes are covering the ditch surface. For diuron, the impact of chemical weeding and mowing on the evolution of the ditch retention capacities was also limited. The inputs of litter after chemical weeding and particularly after mowing slightly increased the retention capacity of ditches. For glyphosate, dredged ditches had lower diuron retention capacities than the control ditches throughout the year. 
Burning, however, increased the diuron retention capacity of the ditches by almost $50 \%$ during the period when ashes are covering the ditch surface.

In the study area, the herbicide spraying period stretches from April to June (Levavasseur, 2012; Louchart et al., 2001) during the growth of the vines. Accordingly, the peak of herbicide concentrations in runoff water is monitored in April/May, whereas from August to March, the concentrations are relatively low (Louchart et al., 2001). Optimizing the herbicide retention capacity of ditches is therefore particularly important during the growth season, particularly if over the same period there is a high risk of storm events as in the study area. In this respect, the burning practices are welcome since, when ditches are burned in winter, the ashes are covering the ditch surface during spring and summer, which slightly increases the retention of glyphosate and substantially increases that of diuron during that crucial period.

\subsubsection{Biodiversity conservation}

Figures 9 represents the evolution of the ecological indicators or, more precisely, of the ditch conditions that influence the detritivore and auxiliary insects and macrofauna populations. Due to the non-additivity of the three ecological indicators, we present their evolution separately. The duration of the study was divided into three periods to facilitate the description of the indicator evolutions. The period from March to May is a crucial period for animal and insect biodiversity, as it corresponds to the breeding season of most species in the study area. This duration includes the beginning of the first and the third periods.

In the control treatment, the vegetation was dense in late summer and fall, and blooming flowers were abundant in the ditch until December 2015 and again from March 2016, but the litter layer was rather scattered throughout the year. In accordance, the indicator scores were high for the canopy and vegetation layer during spring to fall but were low for the litter layer. This treatment thus most likely generates conditions that favour the development and the survival of pollinators and small animals (e.g., Herzon and Helenius, 2008; Meier et al., 2005; Murphy et al., 2012). However, this treatment does not provide ideal conditions for detritivore insects populations (Dangles et al., 2004; Johnson et al., 2003; Murphy et al., 2012)

For the dredging treatments, the vegetation remained scattered throughout the year, and the litter layer and blooming flower were only abundant at the beginning of the second period. Accordingly, the indicator scores for all layers were low and only reached the same values as the control during the last period. Thus, as could be expected, this treatment is unlikely to efficiently sustain the biodiversity in ditches and can even reduce this factor (e.g., Herzon and Helenius, 2008). 
For the mowing treatment, the ecological indicators were highest in the canopy and vegetation layer from April to June, which covers the breeding season. The mowing operations in June and September drastically decreased these scores but increased those of the litter layer. Overall, this treatment most likely generates conditions that favour the development and the survival of auxiliary and detritivore insects (Dangles et al., 2004; Johnson et al., 2003; Murphy et al., 2012) and small animals (e.g., Herzon and Helenius, 2008; Meier et al., 2005; Murphy et al., 2012).

The burning treatment exhibited the same behaviour as the control for the two first periods due to the quick recolonization of the vegetation after the maintenance operation. However, the second burning operation in February 2016 led to very low indicator scores during the third period. Due to the timing of the burning, it can be concluded that this operation, when performed in late winter or spring, can reduce the biodiversity.

The chemical weeding treatment generated low ecological indicator scores during the breeding season and overall improved scores in summer. This treatment is, along with dredging, the least able to sustain a rich biodiversity and can even be detrimental.

In summary, we can rank the management operations in increasing order on biodiversity conservation: dredging, chemical weeding, burning and finally mowing. The differences observed among the different strategies could be related to the maintenance calendar constraints and the plant recolonization dynamics after each treatment.

\section{Discussion}

\subsection{Representativeness and accuracy of the empirical and indicator data}

To our knowledge, the yearly evolution of ditch properties after the common maintenance operations has not yet been described in the literature. However, the literature contains few studies where ditch maintenance strategies and properties were punctually surveyed. In accordance with the literature, our results show that all of the maintenance operations have a direct effect on the removal of the living vegetation (Dollinger et al., 2015). As in our study, the surveys performed by Levavasseur et al. (2014) in the same region also highlighted that the chemically weeded and mowed ditches had higher litter layers than the other types and that all the ditches, regardless of their maintenance design, tended to collect dead leaves during winter. The decrease in the organic carbon content of the ditch 
soil after dredging was similarly reported by several studies across the world (e.g., Smith and Pappas, 2007; Vaughan et al., 2008).

The estimated values of the hydraulic capacity $\left(Q_{\max }\right)$ can be associated with the high uncertainties that stem from both the estimation of vegetation cover (Levavasseur et al., 2014) and the derivation of the Strickler coefficients from the vegetation cover data (Bailly et al., 2015b). However, it must be underlined that the Strickler coefficients over the range of vegetation densities were similar to those measured by Crabit et al. (2011) in similarly vegetated ditches or presented in the Chow tables for small channels (Arcement and Schneider, 1989; Lagacherie et al., 2006). This estimation yields the confidences in the hydraulic capacity trends obtained with this semi-quantitative approach.

The estimation of glyphosate and diuron retention in ditches might also be associated with some uncertainties due, in the one hand, to precision of the ditch properties data and, on the other hand, to the hypotheses underlying the calculation of the SPRI indicator (Dollinger et al., 2016). We found no studies reporting measurement of glyphosate retention rates in ditches that would allow assessing the accuracy of the indicator. However, the average diuron SPRI value for the control treatments was $12 \%$, which is in the range of the diuron retention measured in vegetated ditches with variable litter layers by Margoum et al. (2003). Therefore, the estimation yields the confidences in the herbicide retention capacity trends obtained with this semi-quantitative approach.

The indicators developed to compare the evolution of the biodiversity conservation function in ditches among treatments are entirely qualitative. These indicators allow the discrimination of properties that would either favour or reduce the biodiversity function. However, these indicators do not allow the estimation of the presence or absence of certain categories of insects or animals. Moreover, the thresholds were set based on expert estimations and should be confirmed by additional empirical work.

\subsection{Designing maintenance strategies for sustaining multiple functions}

In the study area, the hydraulic capacity of the ditches needs to be optimal during spring, late summer and fall when high-intensity storms have a high probability of occurrence (Levavasseur et al., 2014; Moussa et al., 2002). Second, the herbicide retention capacity of the ditches needs to be optimal during the growth period and particularly during spring when herbicides are sprayed, which results in high concentrations in the runoff water (Levavasseur, 2012; Louchart et al., 2001). Last, biodiversity must 
be especially sustained in spring and early summer during the breeding season (Herzon and Helenius, 2008).

510

511

512

513

514

515

516

517

518

519

520

521

522

523

524

525

526

527

528

529

530

531

532

533

534

535

536

537

538

539

In this area, dredging and chemical weeding performed once a year in the early spring do not allow the simultaneous optimization of the water conveyance capacity, herbicide retention and biodiversity conservation of the ditches (Table 1). These maintenance designs only allow for the optimization of the hydraulic capacity of the ditches for the spring storms. However, the designs have a null or negative impacts on the other functions during the critical periods when they should be optimal, which includes the hydraulic performance during the late summer and fall storms. However, mowing performed in June and September and burning performed in the winter allows for the optimization of the three investigated functions at least for some of the critical periods (Table 1). Indeed, if mowing is performed too late for the optimization of the hydraulic performance of ditches during the spring floods, the hydraulic performance is still optimized for the late summer and fall floods. Moreover, the dense litter layer produced during the mowing operations increase the retention of hydrophobic herbicides such as diuron. The rapid recolonization by the vegetation after mowing along with the dense litter layer and late flowering sustain biodiversity in ditches from fall until the end of spring. Conversely, burning optimizes the hydraulic capacity for the spring floods but not for the late summer and fall floods. Burning is the maintenance operation that has the greatest impact on herbicides retention and biodiversity during the spring and summer.

For this study, only the succession of single maintenance operations (as opposed to a combination of operations) was investigated on a given ditch. Successions in a period of the two different operations are relatively frequent in the study area (Levavasseur et al., 2014). Successions of burning plus mowing during the year in the same ditch has a probability of occurrence even greater than each operation alone in the study area. The impact of this succession on the multiple functions supported by ditches can be extrapolated from the ditch properties evolution data. Burning performed in February would cover the ditch with ashes during spring and early summer, which optimizes the herbicides retention and limits the vegetation coverage in early spring, which optimizes the hydraulic capacity. The subsequently rapid vegetation recolonization and flowering in spring would help sustain biodiversity. Then, in the late summer when the ditch properties are equivalent to those of an unmanaged ditch, mowing would clear the vegetation. This operation would thereby optimize the hydraulic performance for the late summer and fall floods and generate a dense litter layer that would improve the retention of hydrophobic pesticides. This common succession thereby appears to optimize all the considered functions during all important periods. 
The 4 maintenance operations have similar short-term impacts on ditch vegetation but contrasting impacts on the mid-term evolution of the ditch properties (Fig. 3 to 5). The different biochemical processes involved in the multiple functions supported by ditches are modulated by the ditch properties and thereby by the maintenance operations (Dollinger et al., 2015). These modulations of the water conveyance capacity, herbicide sorption and biodiversity conservation of ditches related to the evolution of ditch properties assessed with the semi-quantitative indicators may be associated with significant uncertainty related both to the precision of the ditch properties data and to the simplification hypothesis inherent to the calculation of the various indicators. However, the range of Strickler coefficients or diuron retention was where the estimated values correspond well to those measured in similar ditches or channels (Crabit et al., 2011b; Margoum et al., 2003), which yields confidence in the trends derived from these indicators.

\section{Conclusion}

This study aimed at characterizing the influence of maintenance on the yearly dynamics of ditch properties in order to identify strategies that would allow simultaneous optimization of a panel of agricultural and ecological functions. The primary maintenance operations of i.e., dredging, chemical weeding, mowing and burning, were shown in this work to lead to significant changes the ditch properties. They all induce vegetation clearance that increases the hydraulic capacity of ditches but decreases their biodiversity support. Moreover, the chemical weeding, and even more mowing generate dense litter layers that improve the retention of hydrophobic herbicides such as diuron and sustain detritivore insects. Furthermore, burning covers the ditch bottom with ashes that greatly increase their herbicide retention capacity. The hydraulic capacity of ditches has to be optimal during the periods when big floods are likely to occur in a given area, while their herbicides retention capacities should be increased during the herbicide-spraying season when concentrations in runoff are likely to be high. Biodiversity should be preferentially sustained during the breeding season. The periods of the year over which these respective ditch functions should be optimal may not overlap. As such, not only the type of maintenance operation but also the calendar of maintenance, by modifying ditch properties at given periods during a year, can help optimizing the multiple ditch functions. The combination of different operations at critical periods of the year allows for the optimization of successively most of the functions that ditches can support. In the Mediterranean context, for example, burning in winter and mowing in late summer is the combination of operation and timing that appears to improve the best of the functions during the crucial periods. 
The evolution of ditch properties after the 4 primary maintenance operations may differ under various pedoclimatic contexts, particularly because the maintenance calendar and operation type chosen are likely to be constrained by the climate. The period over which the different functions of the ditch should be optimized may vary as well. This study, performed in the specific Mediterranean context, provides trends of ditch properties evolutions and of their impact on the ditch hydraulic performance, herbicide retention and biodiversity conservation that may help design maintenance strategies. However, maintenance design should be site-specific and should consider the local problematics of agricultural water management, the environmental problematics and the pedoclimatic context.

\section{Acknowledgments}

We would like to cheerfully thank Mr. Cros and Mr. Boulade for kindly letting us perform the experiments on their ditch. This work was performed in the framework of a research and development project co-funded by the French Office for Water and Aquatic Bodies (ONEMA) and INRA.

\section{References}

Andreassen, H.P., Ims, R.A., Steinset, O.K., 1996. Discontinuous Habitat Corridors: Effects on Male Root Vole Movements. J. Appl. Ecol. 33, 555-560. doi:10.2307/2404984

Arcement, G.J., Schneider, V.R., 1989. Guide for selecting Manning's roughness coefficients for natural channels and flood plains, United State Geological Survey. ed, Water-Supply. Denver, USA.

Bailly, J.S., Dages, C., Dollinger, J., Lagacherie, P., Voltz, M., 2015a. Protocole de spatialisation et d'évolution d'états de surface de fossés (No. 3). INRA.

Bailly, J.S., Vinatier, F., Belaud, G., Combemale, D., 2015b. Vegetation patch effects on flow resistance at channel scale, in: E-Proceedings of the 36th IAHR World Congress. IAHR, The Hague, Netherlands, pp. 1-5.

Boutron, O., Margoum, C., Chovelon, J.-M., Guillemain, C., Gouy, V., 2011. Effect of the submergence, the bed form geometry, and the speed of the surface water flow on the mitigation of pesticides in agricultural ditches. Water Resour. Res. 47, n/a-n/a. doi:10.1029/2011WR010378

Chester, E.T., Robson, B.J., 2011. Drought refuges, spatial scale and recolonisation by invertebrates in non-perennial streams. Freshw. Biol. 56, 2094-2104. doi:10.1111/j.1365-2427.2011.02644.x

Crabit, A., Colin, F., Bailly, J., Ayroles, H., Garnier, F., 2011. Soft Water Level Sensors for Characterizing the Hydrological Behaviour of Agricultural Catchments. Sensors 11, 46564673. doi:10.3390/s110504656

Crabit, Colin, F., Moussa, R., 2011. A soft hydrological monitoring approach for comparing runoff on a network of small poorly gauged catchments. Hydrol. Process. 25, 2785-2800.

Dages, C., Samouëlian, A., Negro, S., Storck, V., Huttel, O., Voltz, M., 2015. Seepage patterns of Diuron in a ditch bed during a sequence of flood events. Sci. Total Environ. 537, 120-128. doi:10.1016/j.scitotenv.2015.07.130

Dangles, O., Gessner, M.O., Guerold, F., Chauvet, E., 2004. Impacts of stream acidification on litter breakdown: implications for assessing ecosystem functioning. J. Appl. Ecol. 41, 365-378. 
Dollinger, J., Dagès, C., Bailly, J.-S., Lagacherie, P., Voltz, M., 2015. Managing ditches for agroecological engineering of landscape. A review. Agron. Sustain. Dev. 35, 999-1020. doi:10.1007/s13593-015-0301-6

Dollinger, J., Dagès, C., Negro, S., Bailly, J.-S., Voltz, M., 2016. Variability of glyphosate and diuron sorption capacities of ditch beds determined using new indicator-based methods. Sci. Total Environ. 573, 716-726. doi:10.1016/j.scitotenv.2016.08.168

Herzon, I., Helenius, J., 2008. Agricultural drainage ditches, their biological importance and functioning. Biol. Conserv. 141, 1171-1183. doi:10.1016/j.biocon.2008.03.005

Jarvela, J., 2002. Flow resistance of flexible and stiff vegetation: a flume study with natural plants. J. Hydrol. 269, 44-54. doi:http://dx.doi.org/10.1016/S0022-1694(02)00193-2

Johnson, B.R., Cross, W.F., Wallace, J.B., 2003. Long-term resource limitation reduces insect detritivore growth in a headwater stream. J. North Am. Benthol. Soc. 22, 565-574. doi:10.2307/1468353

Lagacherie, P., Diot, O., Domange, N., Gouy, V., Floure, C., Kao, C., Moussa, R., Robbez-Masson, J.M., Szleper, V., 2006. An indicator approach for describing the spatial variability of artificial stream networks with regard to herbicide pollution in cultivated watersheds. Ecol. Indic. 6, 265-279. doi:10.1016/j.ecolind.2005.02.003

Lecce, S.A., Pease, P.P., Gares, P.A., Wang, J., 2006. Seasonal controls on sediment delivery in a small coastal plain watershed, North Carolina, USA. Geomorphology 73, 246-260. doi:10.1016/j.geomorph.2005.05.017

Levavasseur, F., 2012. Structure du paysage et fonctionnement hydrologique : application aux réseaux de fossés en zone viticole méditerranéenne. Montpellier SupAgro, Montpellier, France.

Levavasseur, F., Bailly, J.S., Lagacherie, P., 2016. Are ditch networks optimised for mitigating rill erosion in cultivated Mediterranean landscapes? A numerical experiment. Land Use Policy 50, 441-448. doi:10.1016/j.landusepol.2015.08.033

Levavasseur, F., Bailly, J.S., Lagacherie, P., Colin, F., Rabotin, M., 2012. Simulating the effects of spatial configurations of agricultural ditch drainage networks on surface runoff from agricultural catchments. Hydrol. Process. doi:10.1002/hyp.8422

Levavasseur, F., Biarnès, A., Bailly, J.S., Lagacherie, P., 2014. Time-varying impacts of different management regimes on vegetation cover in agricultural ditches. Agric. Water Manag. 140, 14-19. doi:10.1016/j.agwat.2014.03.012

Louchart, X., Voltz, M., Andrieux, P., Moussa, R., 2001. Herbicide Transport to Surface Waters at Field and Watershed Scales in a Mediterranean Vineyard Area. J. Environ. Qual. 30, 982-991.

Margoum, C., Gouy, V., Laillet, B., Dramais, G., 2003. Rétention des produits phytosanitaires dans les fossés de connexion parcelle-cours d'eau. J. Water Sci. 16, 389-405.

Marja, R., Herzon, I., 2012. The importance of drainage ditches for farmland birds in agricultural landscapes in the Baltic countries: does field type matter? Ornis Fenn. 89, 170-181.

Meier, K., Kuusemets, V., Luig, J., Mander, Ü., 2005. Riparian buffer zones as elements of ecological networks: Case study on Parnassius mnemosyne distribution in Estonia. Ecol. Eng. 24, 531537. doi:10.1016/j.ecoleng.2005.01.017

Moussa, R., Voltz, M., Andrieux, P., 2002. Effects of the spatial organization of agricultural management on the hydrological behaviour of a farmed catchment during flood events. Hydrol. Process. 16, 393-412. doi:10.1002/hyp.333

Murphy, S.M., Wimp, G.M., Lewis, D., Denno, R.F., 2012. Nutrient Presses and Pulses Differentially Impact Plants, Herbivores, Detritivores and Their Natural Enemies. PLoS ONE 7, e43929. doi:10.1371/journal.pone.0043929

Needelman, Kleinman, P.J.A., Strock, J.S., Allen, A.L., 2007. Improved management of agricultural drainage ditches for water quality protection: An overview. J. Soil Water Conserv. 62, 171178. 
Nicholls, C.I., Parrella, M., Altieri, M.A., 2001. The effects of a vegetational corridor on the abundance and dispersal of insect biodiversity within a northern California organic vineyard. Landsc. Ecol. 16, 133-146.

Reichenberger, S., Bach, M., Skitschak, A., Frede, H.-G., 2007. Mitigation strategies to reduce pesticide inputs into ground- and surface water and their effectiveness; A review. Sci. Total Environ. 384, 1-35. doi:10.1016/j.scitotenv.2007.04.046

Sarthou, J.P., Ouin, A., Arrignon, F., Barreau, G., Bouyjou, B., 2005. Landscape parameters explain the distribution and abundance of Episyrphus balteatus (Diptera: Syrphidae). Eur. J. Entomol. 102, 539-545.

Schultz, R.C., Collettil, J.P., Isenhart, T.M., Simpkins, W.W., Mize, C.W., Thompson, M.L., 1995. Design and placement of a multi-species riparian buffer strip system. Agrofor. Syst. 29, 201-226. doi:10.1007/BF00704869

Smith, D.R., Pappas, E.A., 2007. Effect of Ditch Dredging on the Fate of Nutrients in Deep Drainage Ditches of the Midwestern United States. J. Soil Water Conserv. 62, 252-261.

Stehle, S., Elsaesser, D., Gregoire, C., Imfeld, G., Niehaus, E., Passeport, E., Payraudeau, S., Schäfer, R.B., Tournebize, J., Schulz, R., 2011. Pesticide risk mitigation by vegetated treatment systems: a meta-analysis. J. Environ. Qual. 40, 1068-1080. doi:10.2134/jeq2010.0510

Stella, J.C., Rodríguez-González, P.M., Dufour, S., Bendix, J., 2013. Riparian vegetation research in Mediterranean-climate regions: common patterns, ecological processes, and considerations for management. Hydrobiologia 719, 291-315. doi:10.1007/s10750-012-1304-9

Steward, A.L., von Schiller, D., Tockner, K., Marshall, J.C., Bunn, S.E., 2012. When the river runs dry: human and ecological values of dry riverbeds. Front. Ecol. Environ. 10, 202-209. doi:10.1890/110136

Strickler, A., 1923. Contributions to the question of a velocity formula and roughness data for streams, channels and closed pipelines.

Tang, X., Zhu, B., Katou, H., 2012. A review of rapid transport of pesticides from sloping farmland to surface waters: Processes and mitigation strategies. J. Environ. Sci. 24, 351-361. doi:10.1016/S1001-0742(11)60753-5

Vaughan, R.E., Needelman, B.A., Kleinman, P.J.A., Rabenhorst, M.C., 2008. Morphology and Characterization of Ditch Soils at an Atlantic Coastal Plain Farm. Soil Sci. Soc. Am. J. 72, 660. doi:10.2136/sssaj2006.0102

Vinatier, F., Bailly, J.-S., Belaud, G., In Press. From3D grassy vegetation point cloud to hydraulic resistance grassy vegetation point cloud to hydraulic resistance: Application to close-range estimation of Manning coefficients for intermittent open channels. Ecohydrology. doi:10.1002/eco.1885

Ward, S.A., 1992. Environmental Uncertainty and Polyphagy in Herbivorous Insects. Oikos 63, 506512. doi:10.2307/3544978

Wishart, M.J., 2000. The terrestrial invertebrate fauna of a temporary stream in southern Africa. Afr. Zool. 35, 193-200. doi:10.1080/15627020.2000.11657090

Wu, F.C., Hsieh Wen, S., Chou, Y.-J., 1999. Variation of roughness coefficients for unsubmerged and submerged vegetation. J. Hydraul. Eng. 125, 934-942. 


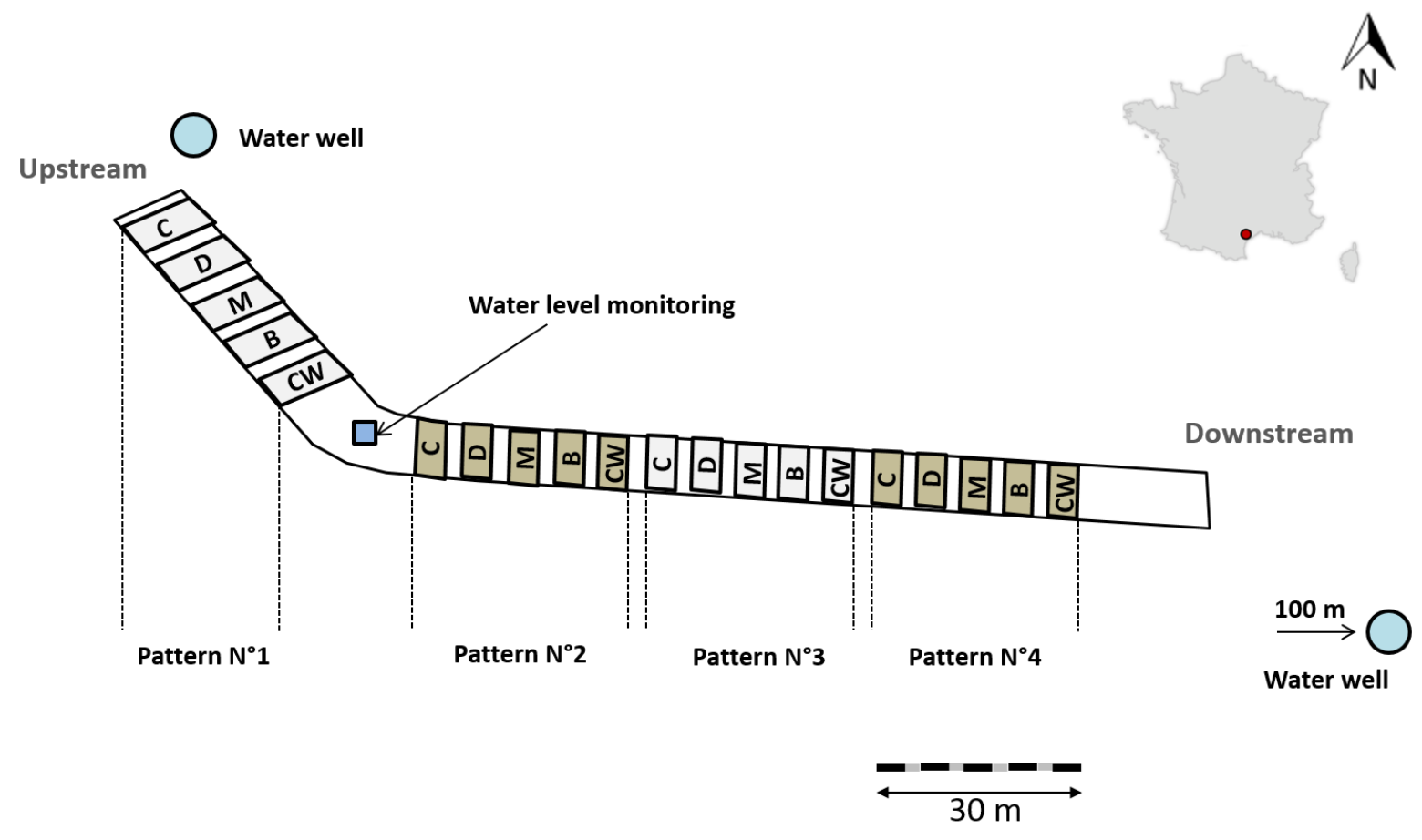

Fig. 1: Experimental design. For each pattern, the quadrats $C, D, M, B, C W$ were respectively unmanaged (control), dredged, mowed, burned and chemically weeded with frequencies and timing that apply to farmers in the study area. Each pattern is $30 \mathrm{~m}$ long, quadrats are $4 \mathrm{~m}$ long each and are separated by $2 \mathrm{~m}$ long buffer sections.

721 


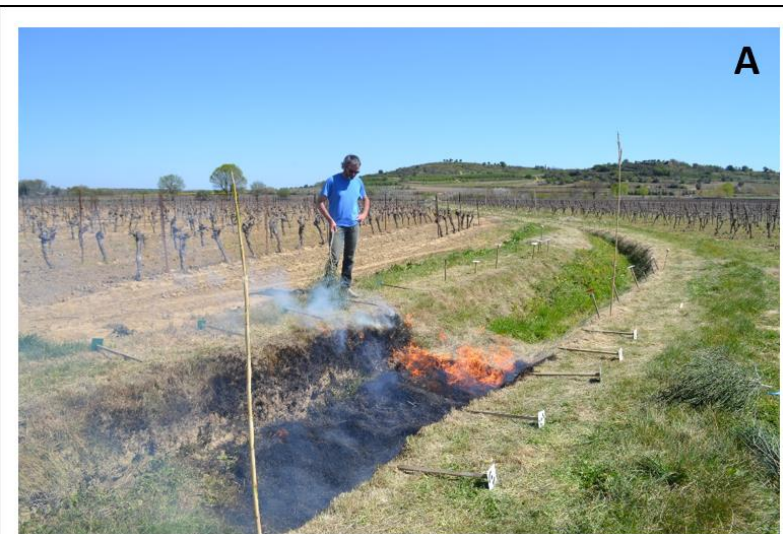

A
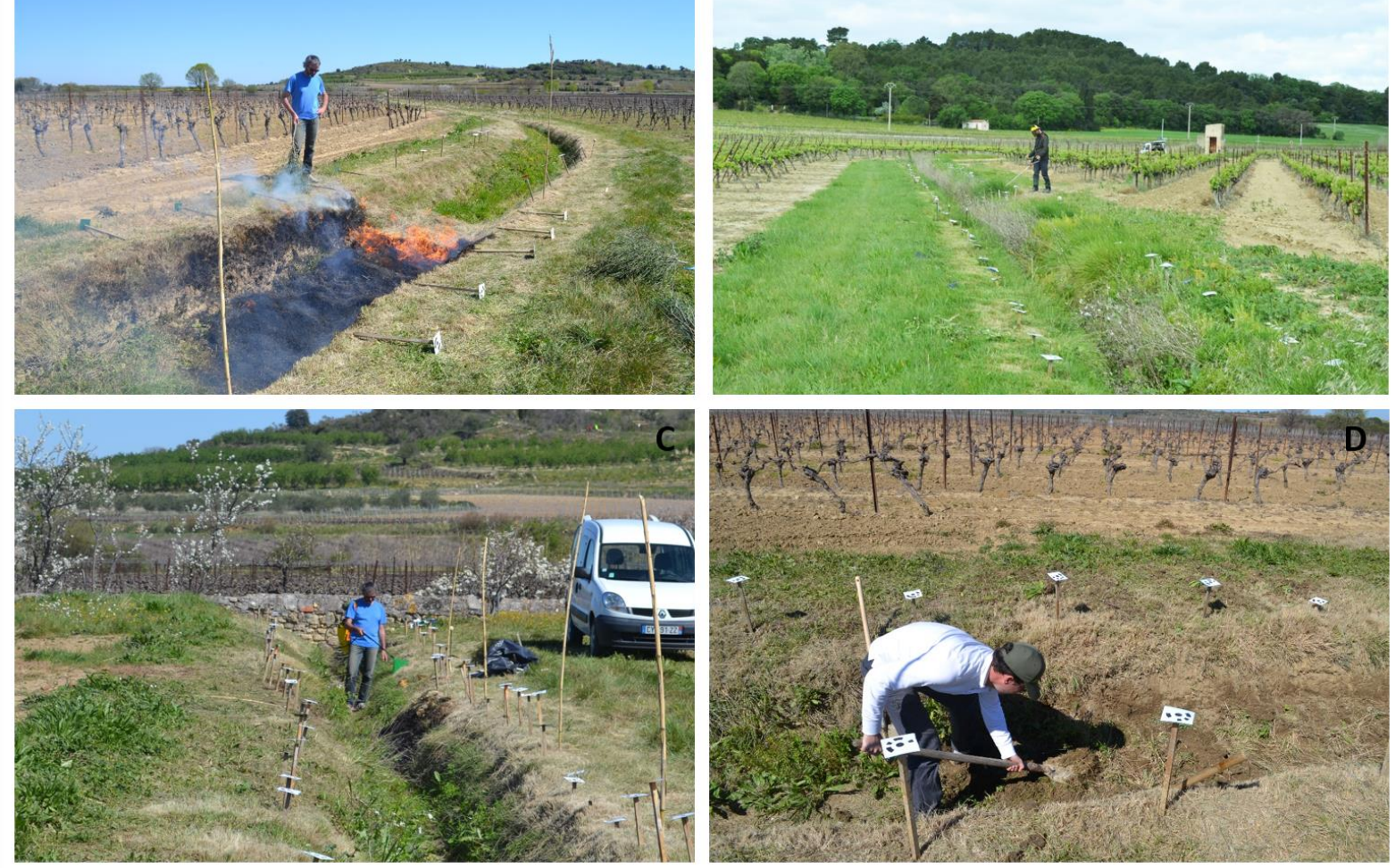

Fig. 2: Ditch maintenance. A: burning; B: mowing; C: chemical weeding and D: dredging. During the burning operation the fire was contained in the $4 \mathrm{~m}$ long sections by suffocating the flames with broom branches. Mowing was done manually using a strimmer. Chemical weeding was performed by 

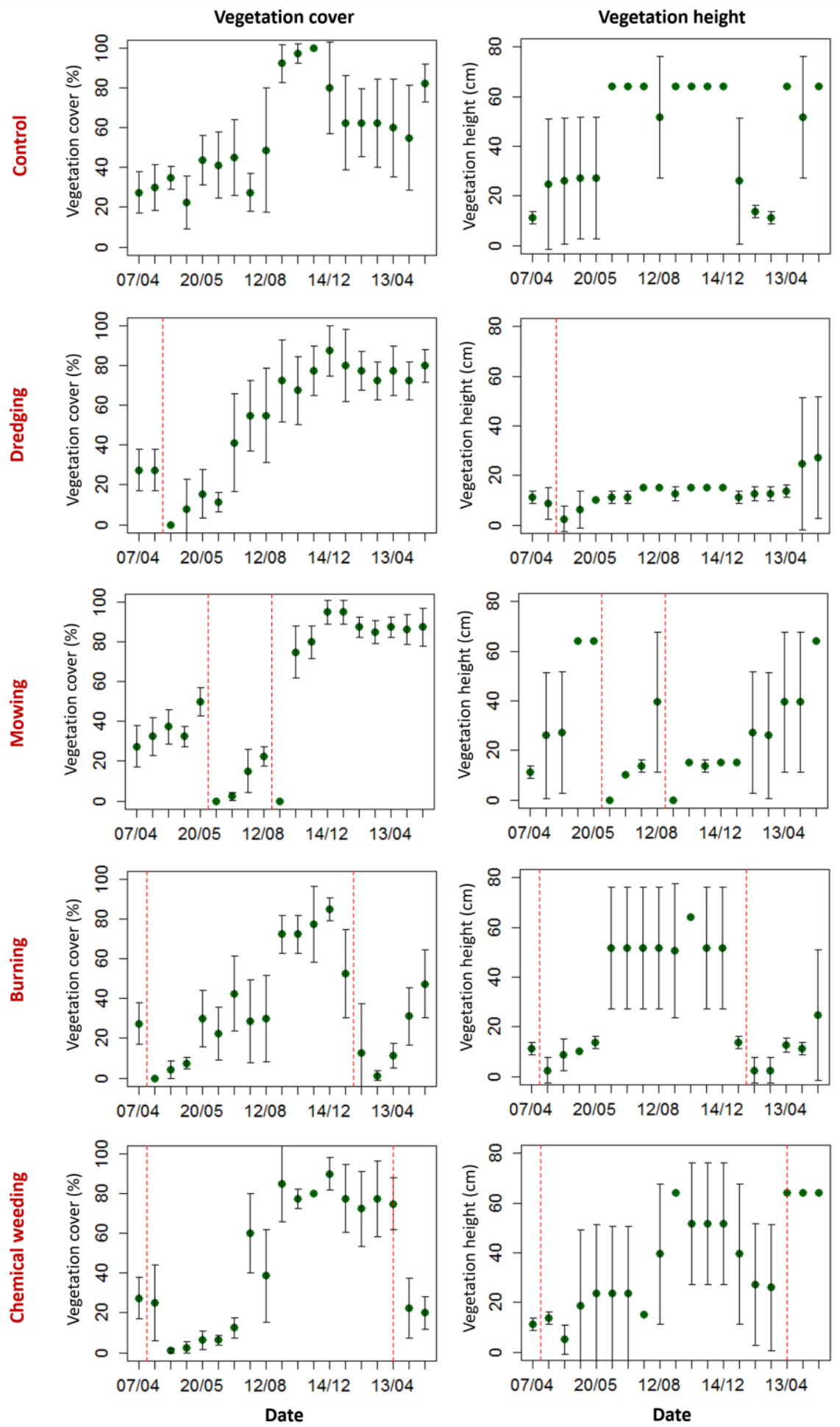

Fig. 3: Yearly evolution of vegetation in the ditches. From top to bottom, the graphs picture the evolution of the vegetation cover in the unmanaged, chemically weeded, mowed, dredged and burned ditches. The graphs in the left column represent the evolution of the ditch bottom surface area covered by vegetation and the graphs on the right the vegetation height. The red dashed lines represent the calendar of the maintenance operations. The green dots represent the mean value among the 4 replicates of each treatment and the vertical bars represent the standard deviations. 

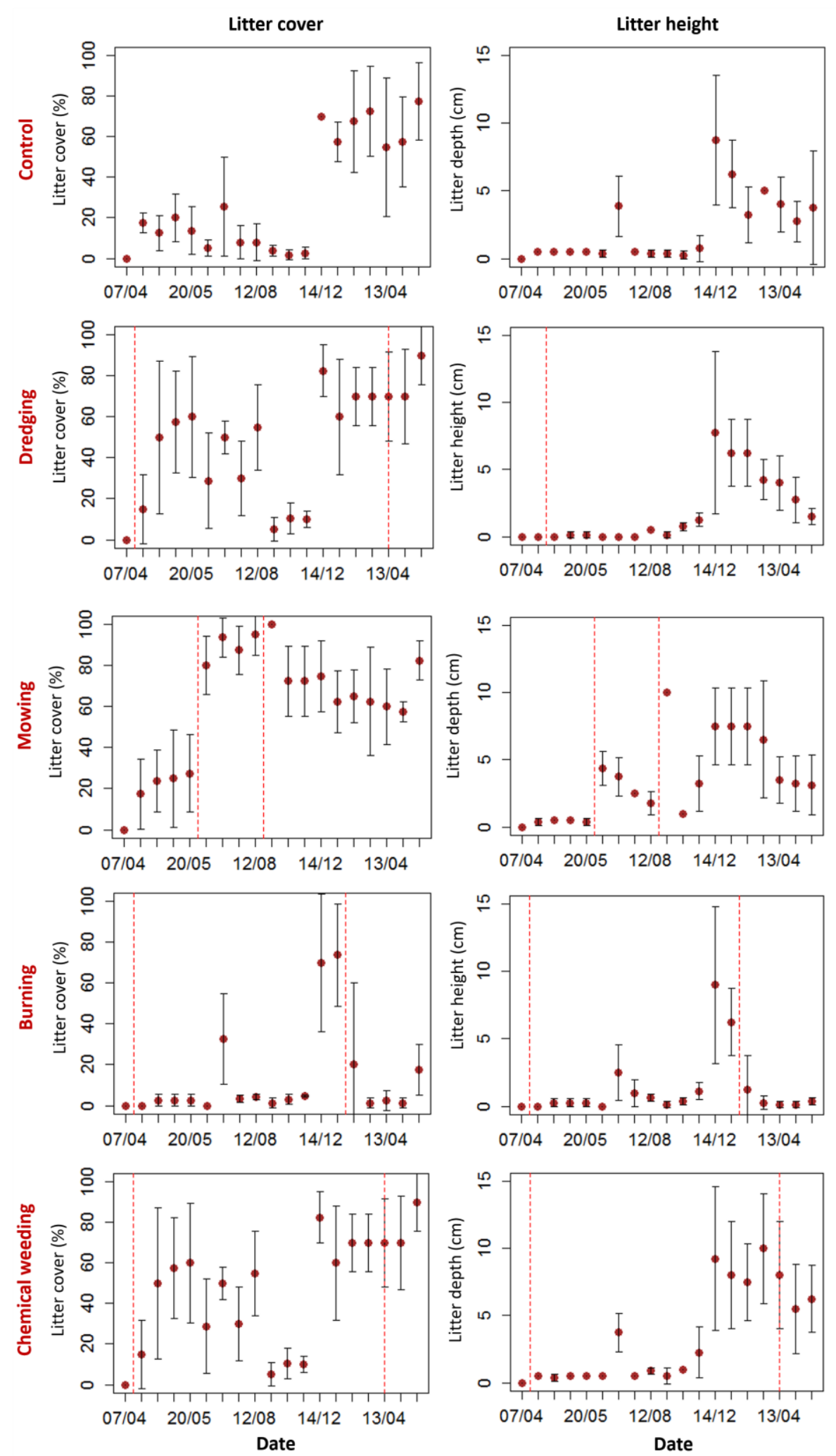

Fig. 4: Yearly evolution of litter in ditches. From top to bottom, the graphs picture the evolution of the vegetation cover in the unmanaged, chemically weeded, mowed, dredged and burned ditches. The graphs in the left column represent the evolution of the ditch bottom surface area covered by litter, and the graphs on the right represent the litter height. The red dashed lines represent the calendar of the maintenance operations. The brown dots represent the mean value among the 4 replicates of each treatment and the vertical bars represent the standard deviations. 

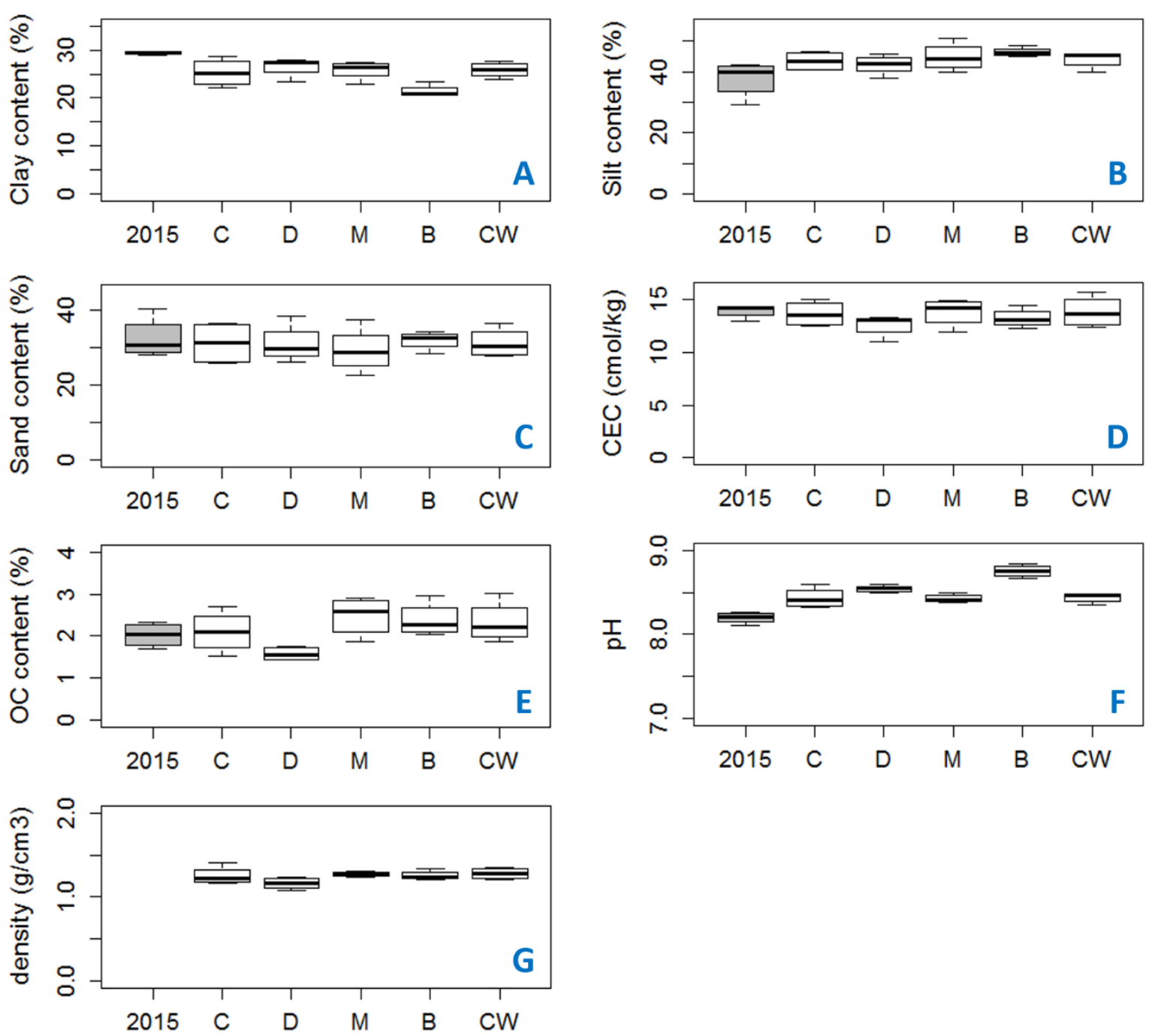

Fig. 5: Ditch top soil physicochemical properties. A: clay content (\%), B: silt content (\%), C: sand content (\%); D: cation exchange capacity $\left(\mathrm{cmol} \mathrm{kg}^{-1}\right)$, E: organic carbon content (\%), $\mathbf{F}$ : $\mathrm{pH}$, G: density $\left(\mathrm{g} \mathrm{cm}^{-3}\right)$. For each soil property, the distribution of the values are given from the left to the right for the control quadrats in 2015 (2015), the control quadrats in 2016 (C), the dredged quadrats in 2016 $(D)$, the mowed quadrats in $2016(M)$, the burned quadrat in 2016 (B) and the chemically weeded 

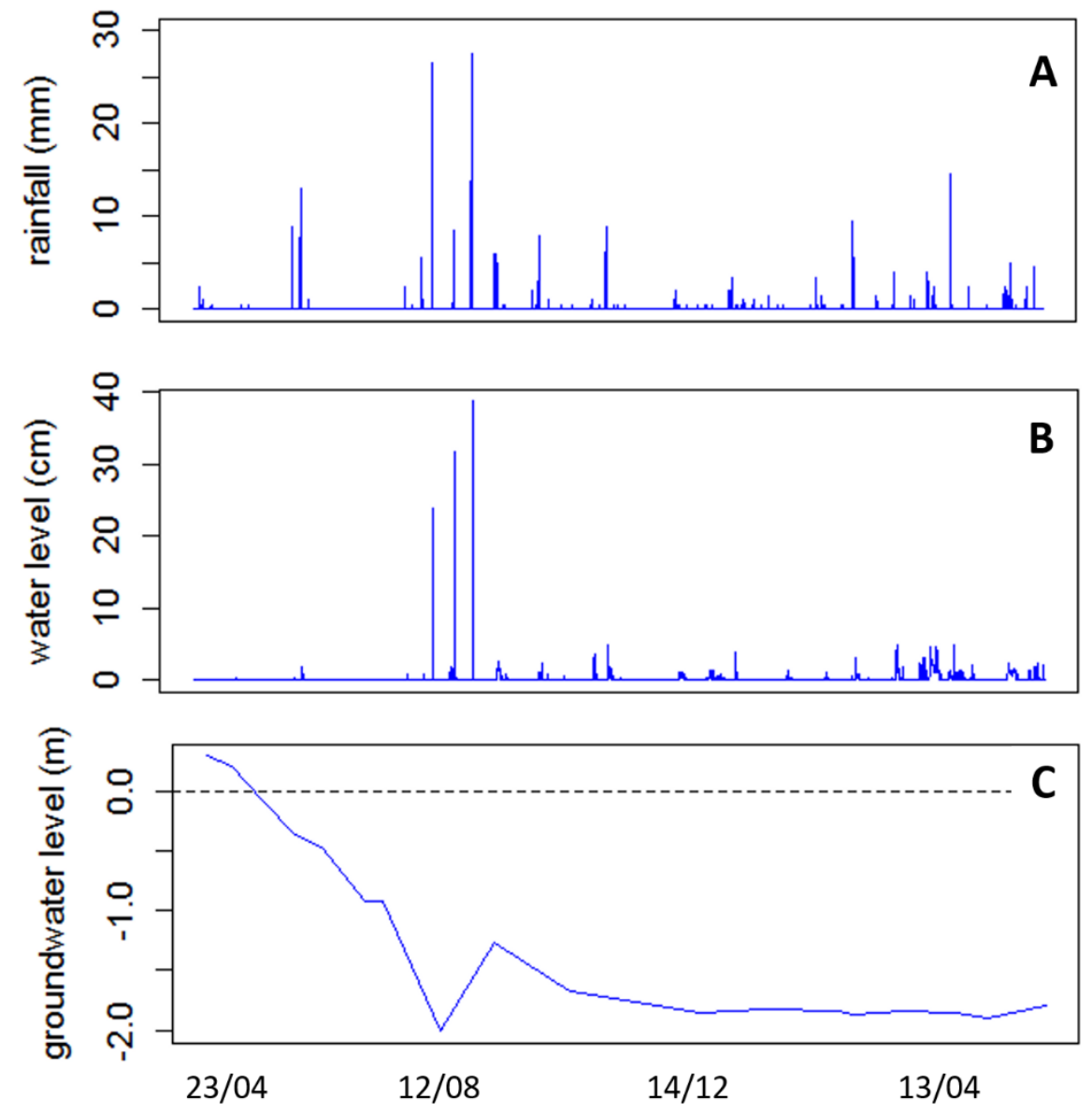

Fig. 6: Hydrology of the study site from April 2015 to May 2016. A: rainfall, B: water level in the ditch, $C$ : groundwater level relative to the ditch bottom. The dashed black line represents the ditch bottom level. 

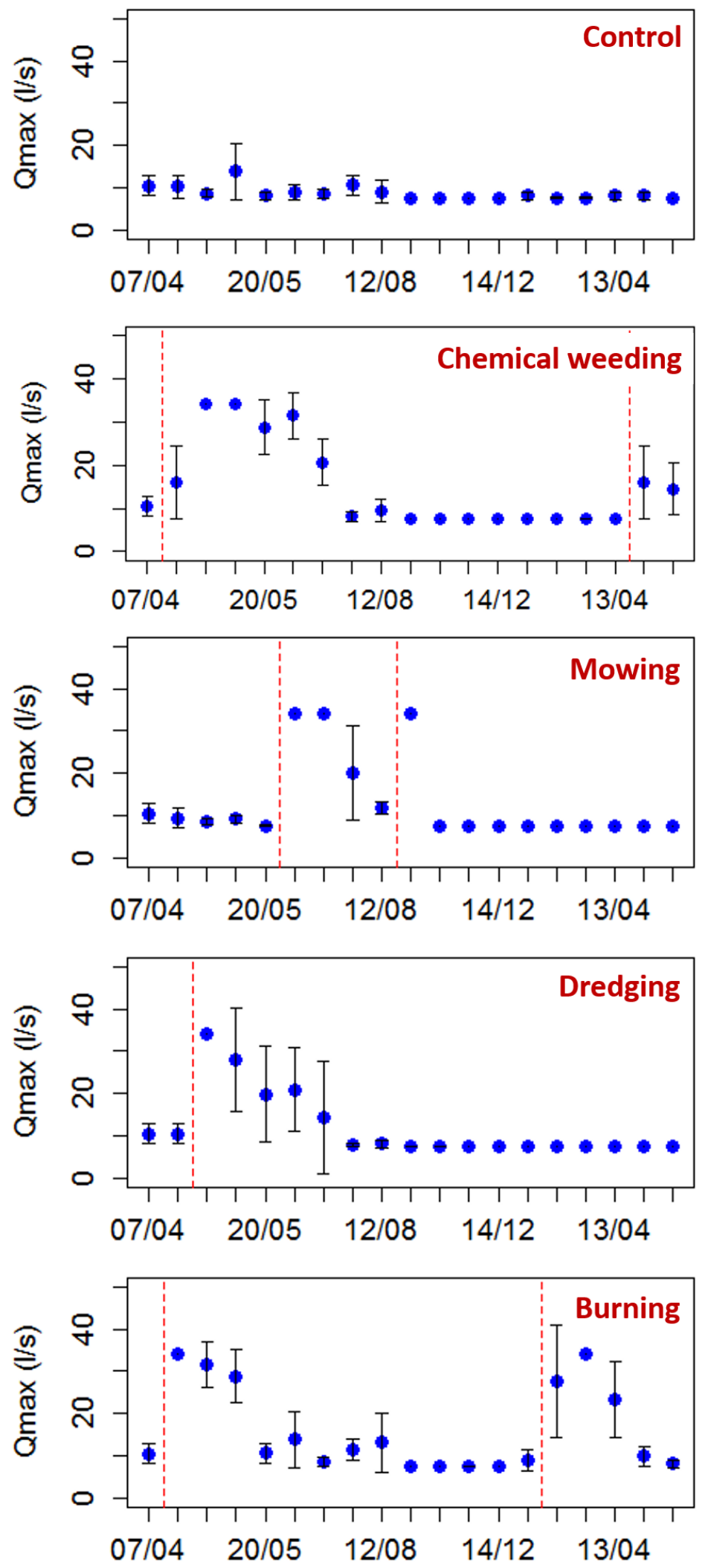

Fig. 7: Ditch hydraulic capacity evolutions. The red dashed lines represent the calendar of the maintenance operations. The blue dots represent the mean value among the 4 replicates of each 
Diuron retention capacity
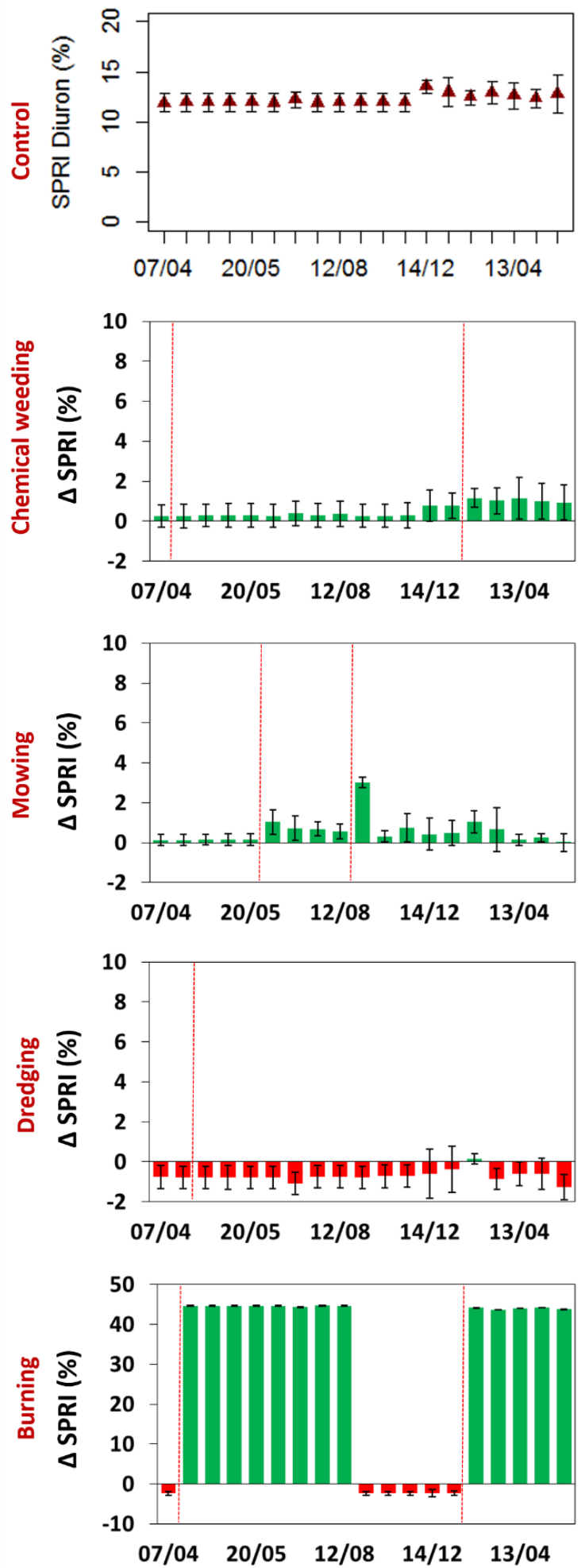

Glyphosate retention capacity
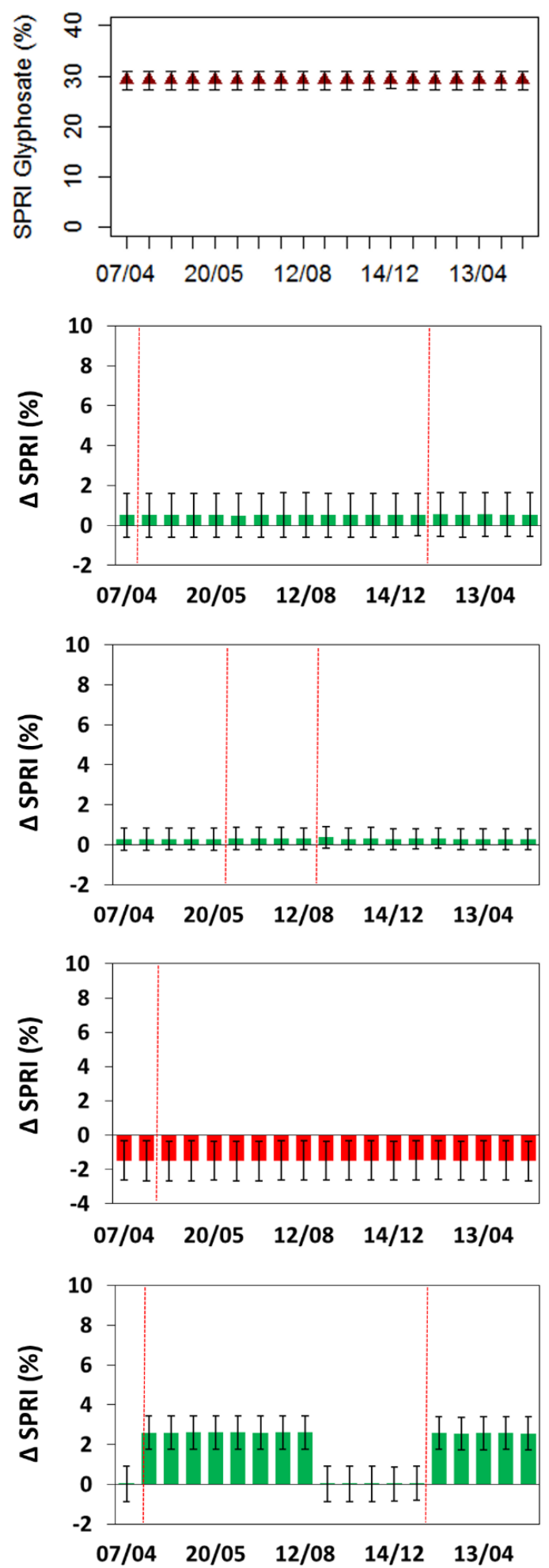

Fig. 8: Herbicide retention capacity (SPRI) evolutions. The $\triangle$ SPRI represents the difference between the SPRI values of the ditches, which are respectively chemically weeded, mowed, dredged and burned relative to the SPRI value of the control ditch at the same dates. The red dashed lines represent the calendar of the maintenance operations. The vertical bars represent the standard 


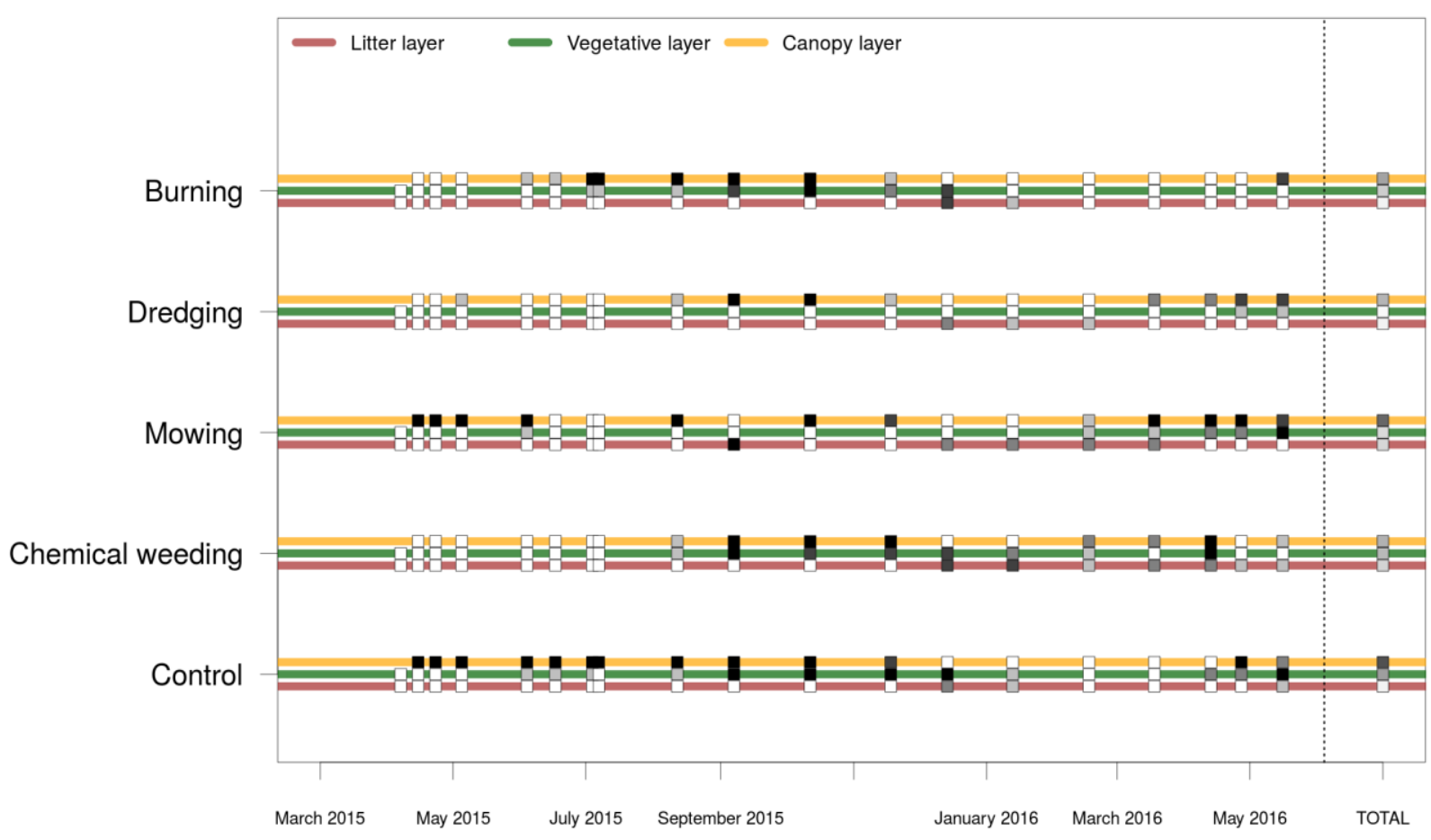

Fig. 9: Biodiversity indicator evolution. Each square is filled with a grey level from 0 (white) to 1 (black) that represents the mean level of biodiversity indicator per layer across the four patterns, except for the last column that represents the mean biodiversity indicator per layer across the four patterns and the 19 dates. 
Table 1: The influence of ditch maintenance strategies on their hydraulic capacity, herbicide retention and ecological functions

\begin{tabular}{|c|c|c|c|c|c|c|c|c|c|c|c|c|c|}
\hline & April & May & June & July & August & September & October & November & December & January & February & March & April \\
\hline $\begin{array}{l}\text { Key periods during } \\
\text { which the hydraulic } \\
\text { capacity, herbicide } \\
\text { retention and } \\
\text { ecological functions } \\
\text { should be optimized }\end{array}$ & $\approx$ & 8 & 28 & 88 & .988 & $\approx$ & $\approx$ & $\approx$ & & & & & 2 \\
\hline Dredging strategy & + & + & + & + & & & & & & & & 0 & - \\
\hline Mowing strategy & $\bullet$ & 0 & $\begin{array}{l}+ \\
\Delta\end{array}$ & $\begin{array}{l}+ \\
\Delta\end{array}$ & $\Delta$ & $\begin{array}{l}+ \\
\Delta\end{array}$ & $\begin{array}{l}+ \\
\Delta\end{array}$ & $\Delta$ & & & & 0 & - \\
\hline Burning strategy & $\begin{array}{l}+ \\
\Delta\end{array}$ & $\begin{array}{l}+ \\
\Delta\end{array}$ & $\Delta$ & $\Delta$ & $\Delta$ & $\bullet$ & 0 & 0 & - & & $\begin{array}{l}+ \\
\Delta\end{array}$ & $\begin{array}{l}+ \\
\Delta\end{array}$ & $\begin{array}{l}+ \\
\Delta \\
+\end{array}$ \\
\hline $\begin{array}{l}\text { Chemical weeding } \\
\text { strategy }\end{array}$ & + & + & + & + & & ○ & - & 0 & & & & ○ & $\Delta$ \\
\hline
\end{tabular}

The blue waves represent the risk of floods and soil erosion, the molecule the periods of high herbicide concentration in runoff and the insect the breeding season in the study area. The months during which each maintenance operations were performed are greyed. The blue crosses represent the periods during which the hydraulic capacity is improved under a given maintenance strategy compared to unmanaged ditches. The red diamonds represent the periods during which the herbicide retention capacity is improved under a given maintenance strategy compared to unmanaged ditches. The green dots represent the periods during which the conditions are favourable for the biodiversity. 